\title{
Simulation of sustainable solid waste management system in Khulna city
}

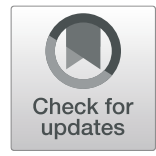

Md Shofiqul Islam* and S. M. Moniruzzaman²

\begin{abstract}
Municipal solid waste management (MSWM) is the major environmental concern for Khulna, the third largest city of Bangladesh. The aim of the study was to determine the most environmentally friendly option of MSWM system for Khulna city. The present system of MSWM in Khulna city was chosen as the baseline scenario in which recycling, composting and landfilling are 9.1, 4.4 and 86.5\% respectively of the total managed waste. Different scenarios were developed by varying the percentage of recycling, composting and landfilling. The life cycle inventory analysis of MSWM system was done by integrated waste management model for each scenario. The model outputs of each scenario were classified into impact categories: emission of the following pollutants: greenhouse gases, acidic gases, smog precursors, heavy metal and organics to air and to water as well as quantity of residual waste and energy consumption or recovery. In the context of the aforesaid impact categories, scenario 7 consist of $71 \%$ composting, $13.6 \%$ recycling and $15.4 \%$ landfilling is the most favorable alternative for Khulna city.
\end{abstract}

Keywords: Municipal solid waste, Life cycle assesment, Greenhouse gases, Energy consumption

\section{Introduction}

Sustainable management of municipal solid waste (MSW) is a critical issue of the municipal authority in most of the cities in the world because of the growing volume of waste and the presence of harmful chemicals and additives in different waste fractions [1-3]. In Bangladesh, MSW management (MSWM) system is not well-organized and generally based on collection and dumping of MSW [4]. In Khulna city, the quantity of total generated MSW is 420 to $520 \mathrm{t} \mathrm{d}^{-1}$ and the Khulna city corporation (KCC) authority is responsible for waste management [5]. By door to door collection system, MSW are generally deposited in secondary disposal sites (SDS) either by the dwellers themselves or community based organizations or non-government organizations [6]. KCC performs MSWM through transportation of MSW from SDS to the final disposal sites (FDS) at Rajbandh, about $7 \mathrm{~km}$ away from the main city [7]. The existing practice of MSWM has led to various emissions of greenhouse gases (GHG) such as carbon dioxide from the production of new materials and methane from the decomposition of organic waste in landfills [8]. Similarly, uncontrolled disposal of MSW is a latent reason for water pollution, public health problems, explosion and landslide.

The Waste Framework Directive does not state which assessment method should be used if deviating from the waste hierarchy, but one of the possibilities is life cycle assessment (LCA), which starts as an assessment method for products but has, since the early 1990s, begun to be used on waste management as well [9]. Also LCA is an effective decision supporting tool associated with a product, process or service from cradle to grave and from production of the raw materials to final disposal of wastes for assessing different approaches of waste management through examining environmental impacts [10-13]. In Khulna city, a few studies have been found to assess the sustainable MSWM by applying LCA methodology. The aim of the present study is to determine the sustainable solid waste management system emphasizing on recycling and composting for Khulna city through LCA.

\footnotetext{
* Correspondence: ngdcshopon@gmail.com

${ }^{1}$ Institute of Disaster Management, Khulna University of Engineering \&

Technology, Khulna 9203, Bangladesh

Full list of author information is available at the end of the article
}

(c) The Author(s). 2019 Open Access This article is distributed under the terms of the Creative Commons Attribution 4.0 International License (http://creativecommons.org/licenses/by/4.0/), which permits unrestricted use, distribution, and reproduction in any medium, provided you give appropriate credit to the original author(s) and the source, provide a link to the Creative Commons license, and indicate if changes were made. The Creative Commons Public Domain Dedication waiver (http://creativecommons.org/publicdomain/zero/1.0/) applies to the data made available in this article, unless otherwise stated. 


\section{Materials and methods}

\section{Study area}

In Bangladesh, Khulna is situated below the tropic of cancer, around the intersection of latitude $22.49^{\circ} \mathrm{N}$ and longitude $89.34^{\circ} \mathrm{E}$. Being the third largest city of country, the encompassing city has an estimated population of 1.5 million. The city has 31 wards, an estimated total land area of $47 \mathrm{~km}^{2}$, and the population density of $67,994 \mathrm{~km}^{-2}$ [5]. The whole city area was selected for the survey area. There is a separate department for the MSWM in KCC namely conservancy department. The location of study area in context of Bangladesh as shown in Fig. 1.

\section{Survey in study area}

A series of field surveys were done to find the amount of MSW used for landfilling, composting and recycling. The field surveys were conducted at each location of SDS, large hauled container points (LHCP), small hauled container points (SHCP), and distinct collection routes (DCR) throughout the city. Countless questionnaire surveys were done with the drivers of waste collection vehicles, employees of conservancy department of KCC, workers of waste collection vehicles and landfill management to collect the quantity of fuel used in collection and transportation of MSW. It is to be noted that the three major seasons are winter season (December to February), summer season (March to May) and rainy season (June to September) in Bangladesh. For the simplicity of research, the year was sub-divided into the two season, i.e., dry season (October to March) and wet season (April to September). Moreover, the amount of MSW from each location of SDS, LHCP, SHCP and DCR was recorded throughout the entire November 2016 for the dry season and throughout the entire July 2017 for the wet season.

\section{Life cycle inventory analysis}

The life cycle inventory analysis was done by an integrated waste management (IWM)-2.0 model which is an Excel TM model with a visual basic graphical interface [14]. In Europe, South America and Asia, the IWM model is designed as a decision supporting tool to decide between various options for waste management in industry as well as local government [15-18].

The major input values of the model were composition of MSW, amount of recycled MSW, amount of composted MSW, amount of landfilled MSW, average driven

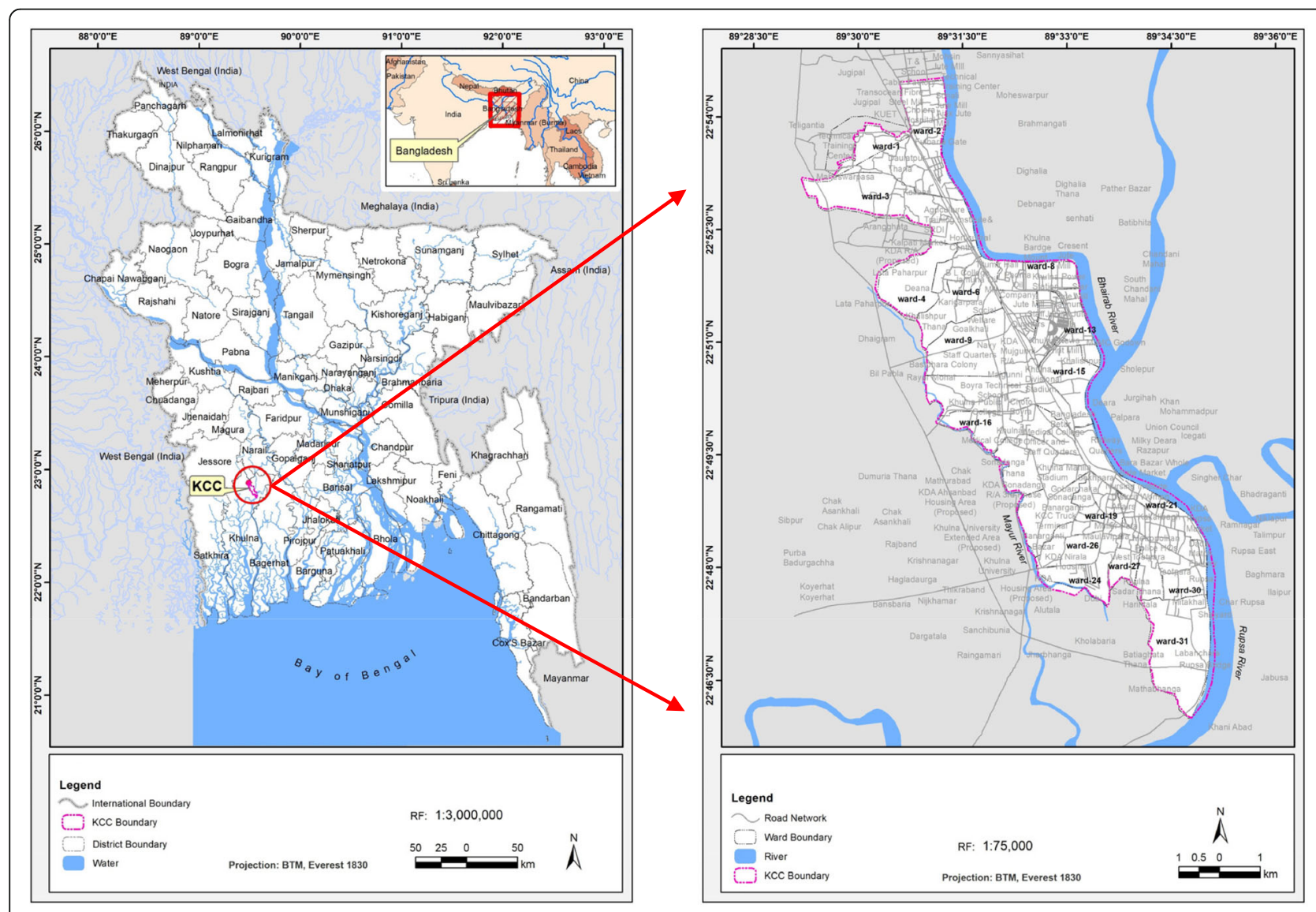

Fig. 1 Location of study area in context of Bangladesh 
distance by collection and transportation vehicles, and quantity of fuel consumption. The flow diagram for life cycle inventory analysis is given in Fig. 2. The total quantity of waste collected at the curb (recyclables, organics and garbage) and the composition of the total waste stream were entered in input screen $\mathrm{A}$ of the model. In case of input screen B, the waste flow data such as quantity of waste sent for recycling, composting, land application, energy recovery and landfilling were entered. The data related to the collection and transportation of waste in the system such as distance driven by collection trucks, type of fuel used and fuel efficiency were entered in input screen C. In input screen D, users have the option of choosing the mix of power generation methods, or the average mix of power generation methods. Alternatively, a user can specify a custom grid by selecting the 'custom' option on screen D. 'Custom' button was selected and allowed the user to input the percentage of power generated by each of the generating methods. Input screen $\mathrm{E}$ will only appear if the user has entered a number greater than zero for quantity of waste recycled. The data related to recovery rates was entered on this screen. The data related to energy consumption, percent residue, residue management, distance to markets and distance from material recovery facility to landfill were entered in input screen F. The entered data on input screen $G$ includes breakdown in tons of the materials sent for composting, composition of yard waste, energy consumption and distance from composting facility to landfill. Input screen $\mathrm{H}$ will only appear if the user has entered a number greater than zero for quantity of waste land applied in input screen B. The entered data in this screen were the composition of yard waste and energy consumption. The energy recovered and energy recovery efficiency were entered in input screen I. In input screen J, the data related to gas recovery, energy recovery, annual precipitation and energy consumption were entered. All the data were entered in input screen A to J for each modelled scenario. Due to the space constraint, only the entered data in baseline scenario are shown in Table 1.

The outputs of each scenario were calculated by using IWM model and classified into impact categories: emission of GHGs, emission of acid gases, emission of smog precursors, emission of heavy metal and organics to air, emission of heavy metal and organics to water, quantity of residual waste and energy consumption or recovery. The percent reduction of emission in aforementioned categories compared to baseline scenario was calculated by Eq. (1) as follows:

$$
E R(\%)=\frac{E B-E M}{E B} * 100
$$

where, $\mathrm{ER}=$ Emission reduction, $\mathrm{EB}=$ Emission of baseline scenario and $\mathrm{EM}=$ Emission of modelled scenario. 
Table 1 Details of input data for baseline scenario in IWM model

\begin{tabular}{|c|c|c|}
\hline Particulars in input screens & & Input data \\
\hline \multirow[t]{3}{*}{ Total quantity of managed MSW, $\mathrm{t}$} & Recycled MSW & 37.2 \\
\hline & Composted MSW & 18 \\
\hline & Landfilled MSW & 356 \\
\hline \multirow[t]{13}{*}{ Composition of MSW, \% } & Paper & 9.5 \\
\hline & Glass & 0.5 \\
\hline & Ferrous metal & 1.0 \\
\hline & Aluminum & 0.1 \\
\hline & PET & 0.3 \\
\hline & HDPE & 0.3 \\
\hline & LLDPE & 0.5 \\
\hline & PP & 0.3 \\
\hline & PS & 0.3 \\
\hline & PVC & 1.5 \\
\hline & Food waste & 70 \\
\hline & Yard waste & 8.9 \\
\hline & Other waste & 6.8 \\
\hline \multirow{3}{*}{$\begin{array}{l}\text { Distance driven by collection truck, } \\
\mathrm{km}\end{array}$} & Garbage truck & 2162.3 \\
\hline & Recycling truck & 239.5 \\
\hline & Yard waste truck & 234.3 \\
\hline \multirow[t]{2}{*}{ Diesel fuel efficiency, $\mathrm{km} \mathrm{L}^{-1}$} & Collection truck & 2.25 \\
\hline & Transportation truck & 2.5 \\
\hline \multirow[t]{6}{*}{ Electric grid selection, \% } & Coal & 0 \\
\hline & Natural gas & 0 \\
\hline & $\begin{array}{l}\text { Diesel and light fuel } \\
\text { oil }\end{array}$ & 75 \\
\hline & Heavy fuel oil & 25 \\
\hline & Hydro & 0 \\
\hline & Nuclear & 0 \\
\hline \multicolumn{2}{|l|}{ Management procedure of residue } & Landfilling \\
\hline \multicolumn{2}{|l|}{ Composting process } & In vessel \\
\hline \multicolumn{2}{|l|}{ Gas recovery system } & $\begin{array}{l}\text { Not } \\
\text { available }\end{array}$ \\
\hline \multicolumn{2}{|l|}{ Energy recovery } & $\begin{array}{l}\text { Not } \\
\text { available }\end{array}$ \\
\hline \multicolumn{2}{|l|}{ Annul precipitation, mm } & 2000 \\
\hline \multicolumn{2}{|l|}{ Landfill lining facility } & $\begin{array}{l}\text { Not } \\
\text { available }\end{array}$ \\
\hline \multicolumn{2}{|l|}{ Leachate collection system } & $\begin{array}{l}\text { Not } \\
\text { available }\end{array}$ \\
\hline
\end{tabular}

\section{Results and discussion}

\section{Quantity of collected and transported MSW}

The field survey reveals that there are 11 SHCPs having capacity of $3000 \mathrm{~kg}$ each and 27 large LHCPs having capacity of $5000 \mathrm{~kg}$ each; 12 DCRs and 17 SDSs at different locations in Khulna city. The study also finds that
Table 2 Quantity of collected and transported MSW by KCC in Khulna city

\begin{tabular}{llll}
\hline \multirow{2}{*}{$\begin{array}{l}\text { Name of the sites } \\
\text { Number of sites) }\end{array}$} & \multicolumn{3}{l}{ Quantity of MSW $\left(\mathrm{t} \mathrm{d}^{-1}\right)$} \\
\cline { 2 - 4 } & Dry season & Wet season & Average \\
\hline Secondary disposal sites (17) & 158 & 209.5 & 183.8 \\
$\begin{array}{l}\text { Large hauled container } \\
\text { points (27) }\end{array}$ & 84.3 & 114 & 99.1 \\
$\begin{array}{l}\text { Small hauled container points (11) } \\
\text { Distinct collection routes (12) }\end{array}$ & 68.5 & 15.3 & 15.9 \\
Total & & 82 & 75.3
\end{tabular}

the total quantity of collected and transported MSW from SDS, LHCP, SHCP and DCR to FDS is $374 \mathrm{t} \mathrm{d}^{-1}$ as shown in Table 2. From FDS only $18 \mathrm{t} \mathrm{d}^{-1}$ of MSW is directly used for the composting purpose by non-government organization. Therefore, the quantity of MSW managed through landfilling in FDS is $356 \mathrm{t} \mathrm{d}^{-1}$.

\section{Modelled scenarios}

Table 3 represents the description of seven modelled scenarios for sustainable waste management system in Khulna city. The present practice of MSWM in Khulna is chosen as the baseline scenario in which recycling is considered as $9.1 \%\left(37.23 \mathrm{t} \mathrm{d}^{-1}\right)$ from the authors' another study [7], composting is considered as $4.4 \%\left(18 \mathrm{t} \mathrm{d}^{-1}\right)$ from field investigation and landfilling is considered as $86.5 \%\left(356 \mathrm{t} \mathrm{d}^{-1}\right)$ from field survey of the total managed waste $\left(411.23 \mathrm{t} \mathrm{d}^{-1}\right)$. In modelled scenarios, an incineration technique in MSW management is not considered due to no facility practically in Khulna city. The baseline scenario is used as the reference against which modelled scenarios 1 to 4 are measured. The scenarios 5 to 7 represent the combination of percentage of different MSW management technique. It is to be noted that based on composition of MSW in Khulna city, the maximum percentage of compostable and recyclable MSW is considered in modelled scenario 7 .

Table 3 Description of the modelled scenarios

\begin{tabular}{llll}
\hline Modelled scenarios & Composting (\%) & Recycling (\%) & Landfilling (\%) \\
\hline Baseline scenario (S-0) & 4.4 & 9.1 & 86.5 \\
Scenario 1 (S-1) & 26.3 & 9.1 & 64.6 \\
Scenario 2 (S-2) & 52.6 & 9.1 & 38.3 \\
Scenario 3 (S-3) & 71.0 & 9.1 & 19.9 \\
Scenario 4 (S-4) & 4.4 & 13.6 & 82.0 \\
Scenario 5 (S-5) & 26.3 & 13.6 & 60.1 \\
Scenario 6 (S-6) & 52.6 & 13.6 & 33.8 \\
Scenario 7 (S-7) & 71.0 & 13.6 & 15.4 \\
\hline
\end{tabular}




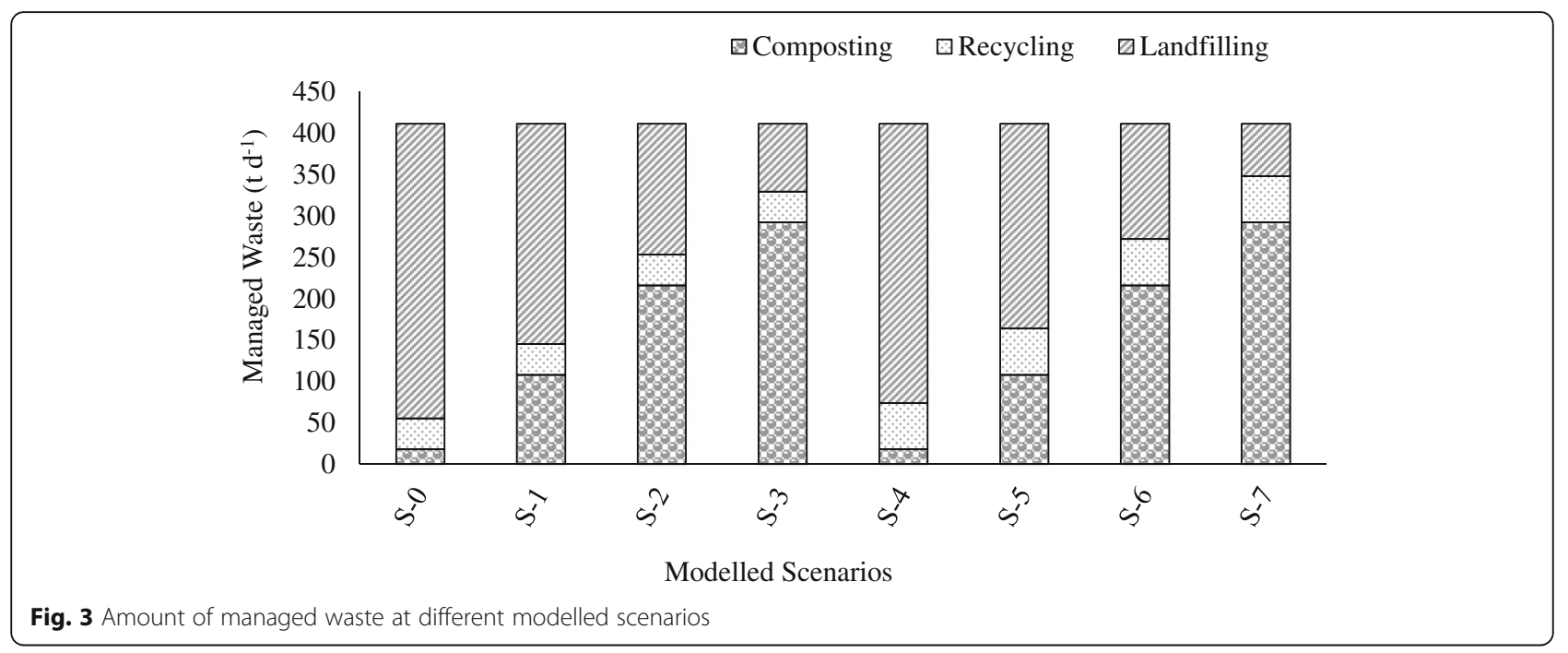

It is estimated that the recyclable waste in the city is about $14.2 \%$, and compostable food and vegetable waste is about $78.9 \%$ from the composition of solid waste of Khulna city [19]. In the scenario 1 (S-1), the composting is increased to six times of the baseline scenario (26.3\%) because of present existing facility of composting technique by a non-government organization named Rural Unfortunates Safely Talisman Illumination Cottage which is locally called RUSTIC, recycling is considered at the same of the baseline scenario (9.1\%) and landfilling is decreased to $64.6 \%$. This scenario emphasizes composting technique of MSW in Khulna city [11]. Smiliarly in the scenario 2 (S-2), the composting is increased to twelve times of baseline scenario (52.6\%), the recycling is considered at the same level of the baseline scenario (9.1\%) and landfilling is decreased (38.3\%). The reason for the further increment of the percentage of composting of MSW is to compare the amount of emission reduction of different environmental parameters. In the scenario $3(\mathrm{~S}-3)$, the composting is increased to the highest level as $71.0 \%$ (i.e., $90 \%$ of compostable food and vegetable waste) due to the available quantity of compostable MSW excluding losses in collection, transportation, and sorting from other MSW, the recycling is at the same of the baseline scenario (9.1\%) and landfilling is decreased (19.9\%).

In the scenario $4(\mathrm{~S}-4)$, the recycling is increased to its highest level of maximum recycleable MSW as $13.6 \%$ excluding 5 to $6 \%$ material losses, composting is considered at the same level of the baseline scenario (4.4\%) and landfilling is decreased (82.0\%).

In case of scenario 5 (S-5), a combination is made through consideration of composting level as similiar to S-1 and recycling level as similar to S-4. In case of scenario 6 (S-6) composting level is considered as similiar to $\mathrm{S}-2$ and recycling level as similar to $\mathrm{S}-4$. In case scenario-7 (S-7), composting level is considered as similiar to S-3 and recycling level as similar to S-4. Figure 3 represents the amount of managed waste at different modelled scenarios.

Table 4 Emission of GHGs from modelled scenarios in net $\mathrm{LCl}$

\begin{tabular}{|c|c|c|c|c|c|c|c|c|}
\hline \multirow{2}{*}{$\begin{array}{l}\text { Modelled } \\
\text { scenarios }\end{array}$} & \multicolumn{7}{|c|}{ Emission of $\mathrm{GHGs}\left(\mathrm{kg} \mathrm{CO}_{2} \mathrm{eq} \mathrm{d}^{-1}\right)$} & \multirow{2}{*}{$\begin{array}{l}\text { Emission } \\
\text { reduction } \\
(\%)\end{array}$} \\
\hline & $\mathrm{R}$ & C & $L$ & TWMS & VMDC & RRM & Net LCl & \\
\hline S-0 & 23.9 & 4900 & 769,833 & 774,757 & $-86,636$ & 31,465 & 719,586 & - \\
\hline S-1 & 23.9 & 29,398 & 580,803 & 610,225 & $-86,636$ & 31,465 & 555,054 & 22.9 \\
\hline S-2 & 23.9 & 58,795 & 353,967 & 412,786 & $-86,636$ & 31,465 & 357,615 & 50.3 \\
\hline $\mathrm{S}-3$ & 23.9 & 79,485 & 194,321 & 273,830 & $-86,636$ & 31,465 & 218,659 & 69.6 \\
\hline S-4 & 36.1 & 4900 & 751,605 & 756,541 & $-130,642$ & 47,447 & 673,346 & 6.4 \\
\hline S-5 & 36.1 & 29,398 & 562,575 & 592,009 & $-130,642$ & 47,447 & 508,814 & 29.3 \\
\hline S-6 & 36.1 & 58,795 & 335,739 & 394,570 & $-130,642$ & 47,447 & 311,376 & 56.7 \\
\hline S-7 & 36.1 & 79,485 & 176,093 & 255,614 & $-130,642$ & 47,447 & 172,419 & 76.0 \\
\hline
\end{tabular}

$R$ Recycling, C Composting, L Landfill, TWMS Total waste management system; VMDC Virgin material displacement credit, RRM Reprocessing of recycled materials, $L C I$ Life cycle inventory 
Table 5 Emission of acidic gases in total waste management system

\begin{tabular}{lllllllll}
\hline Acidic gases & \multicolumn{1}{l}{ Modelled scenarios } \\
\cline { 2 - 9 } & S-0 & S-1 & S-2 & S-3 & S-4 & S-5 & S-6 & S-7 \\
\hline NOx $\left(\mathrm{kg} \mathrm{d}^{-1}\right)$ & 43.6 & 42.0 & 40.2 & 38.8 & 43.4 & 41.8 & 39.9 & 38.6 \\
SOx $\left(\mathrm{kg} \mathrm{d}^{-1}\right)$ & 30.3 & 25.6 & 20.0 & 16.1 & 29.5 & 24.8 & 19.2 & 15.3 \\
$\mathrm{HCl}\left(\mathrm{kg} \mathrm{d}^{-1}\right)$ & 5.9 & 4.4 & 2.7 & 1.5 & 5.7 & 4.3 & 2.5 & 1.3 \\
\hline
\end{tabular}

\section{Life cycle inventory analysis}

Based on the data gathered at the inventory analysis stage, the IWM Model was run for total managed waste of $411.23 \mathrm{t} \mathrm{d}^{-1}$ in each scenario. The results of the simulation were evaluated on the environmental aspects for all the scenarios as described below. It is to be noted that in all tables, positive values indicate energy consumed or emission released and negative values indicate energy recovered or emissions reduced.

Table 4 shows the summary of GHGs emission from different modelled scenarios. The highest emission of GHGs (719.6 $\mathrm{t} \mathrm{CO}_{2}$ eq d $^{-1}$ ) was found in S-0 due to the highest percentage of landfilling (86.5\%) and lowest percentage of recycling (9.1\%) as well as composting (4.4\%). On the other hand the lowest emission of GHGs (172.4 $t$ $\mathrm{CO}_{2}$ eq $\mathrm{d}^{-1}$ ) was found in S-7 due to the lowest percentage of landfilling (15.4\%) and highest percentage of recycling (13.6\%) as well as composting (71.0\%). The maximum reduction of GHGs as calculated by Eq. (1) was found in S-7 as 76\% compared to baseline scenario.

Table 5 shows the acidic gases emission from different modelled scenarios in total waste management system. The emission of acid gases such as Nitrogen Oxides (NOx), Sulfur Oxides (SOx) and Hydrochloric acid $(\mathrm{HCl})$ were calculated by the model. In total waste management system, the highest emission of acidic gases was found in S-0 due to the highest percentage of landfilling (86.5\%) and lowest percentage of recycling (9.1\%) as well as composting (4.4\%). On the other hand the lowest emission of acidic gases was found in S-7 due to the lowest percentage of landfilling (15.4\%) and highest percentage of recycling (13.6\%) as well as composting (71.0\%). In $\mathrm{S}-7$, the maximum reduction of emission of $\mathrm{NOx}, \mathrm{SOx}$ and $\mathrm{HCl}$ was found to be 12,50 and $78 \%$ respectively compared to baseline scenario.

Table 6 Emission of smog precursors in total waste management system

\begin{tabular}{lllllllll}
\hline $\begin{array}{l}\text { Smog } \\
\text { precursors }\end{array}$ & \multicolumn{7}{l}{ Modelled scenarios } \\
\cline { 2 - 9 } & $\mathrm{S}-0$ & $\mathrm{~S}-1$ & $\mathrm{~S}-2$ & $\mathrm{~S}-3$ & $\mathrm{~S}-4$ & $\mathrm{~S}-5$ & $\mathrm{~S}-6$ & $\mathrm{~S}-7$ \\
\hline NOx $\left(\mathrm{kg} \mathrm{d}^{-1}\right)$ & 43.6 & 42.0 & 40.2 & 38.8 & 43.4 & 41.8 & 40.0 & 38.6 \\
PM $\left(\mathrm{kg} \mathrm{d}^{-1}\right)$ & 109.8 & 101.0 & 90.5 & 83.2 & 105.8 & 97.0 & 86.5 & 79.1 \\
VOCs $\left(\mathrm{kg} \mathrm{d}^{-1}\right)$ & 218.7 & 171.1 & 113.9 & 73.7 & 213.9 & 166.2 & 109.0 & 68.8 \\
\hline
\end{tabular}

NOx Nitrogen oxide, PM Particulate matter, VOCs Volatile organic compounds
Table 7 Emission of heavy metal and organics to air in total waste management system

\begin{tabular}{lllll}
\hline \multirow{2}{*}{$\begin{array}{l}\text { Modelled } \\
\text { scenarios }\end{array}$} & \multicolumn{4}{l}{ Emission of heavy metal and organics to air $\left(\mathrm{mg} \mathrm{d}^{-1}\right)$} \\
\cline { 2 - 5 } & Lead & Mercury & Cadmium & Dioxins (TEQ) \\
\hline S-0 & 1858 & 17 & 675 & 0.031 \\
S-1 & 1476 & 15 & 523 & 0.024 \\
S-2 & 1018 & 12 & 340 & 0.015 \\
S-3 & 695 & 9 & 211 & 0.008 \\
S-4 & 1802 & 17 & 658 & 0.030 \\
S-5 & 1420 & 14 & 506 & 0.023 \\
S-6 & 961 & 11 & 323 & 0.014 \\
S-7 & 639 & 9 & 194 & 0.008 \\
\hline
\end{tabular}

TEQ Toxic equivalency

Table 6 shows the emission of smog precursors such as NOx, particulate matter (PM), volatile organic compounds (VOCs). In total waste management system, the highest emission of smog precursors was found in S-0. On the other hand the lowest emission of smog precursors was found in S-7 due to the lowest percentage of landfilling and highest percentage of recycling as well as composting. Also the maximum reduction of emission of NOx, PM, VOCs was found in S-7 as 12, 28 and 69\%, respectively compared to baseline scenario.

Table 7 represents the emission of heavy metal and organics to air in total waste management system. In case of lead emission, the highest emission was found in S-0 as $1858 \mathrm{mg} \mathrm{d}^{-1}$ due to the highest percentage of landfilling. Conversely the lowest emission was found in S-7 as $639 \mathrm{mg} \mathrm{d}^{-1}$ which is $65.6 \%$ lower compared to baseline scenario. In the same way the maximum emission reductions of mercury, cadmium and dioxins were found in S-7 as 47,71 and $76 \%$ respectively compared to baseline scenario.

In case of emission of heavy metal and organics to water in total waste management system, the lowest emission to water was found in S-7 as shown in Table 8.

Table 8 Emission of heavy metal and organics to water in total waste management system

\begin{tabular}{llllll}
\hline $\begin{array}{l}\text { Modelled } \\
\text { scenarios }\end{array}$ & \multicolumn{4}{l}{ Emission of heavy metal and organics to water } \\
\cline { 2 - 6 } & $\begin{array}{l}\text { Lead }(\mathrm{mg} \\
\left.\mathrm{d}^{-1}\right)\end{array}$ & $\begin{array}{l}\text { Mercury } \\
\left(\mathrm{mg} \mathrm{d}^{-1}\right)\end{array}$ & $\begin{array}{l}\text { Cadmium } \\
\left(\mathrm{mg} \mathrm{d}^{-1}\right)\end{array}$ & $\begin{array}{l}\text { BOD }(\mathrm{kg} \\
\left.\mathrm{d}^{-1}\right)\end{array}$ & $\begin{array}{l}\text { Dioxins (TEQ) } \\
\left(\mathrm{mg} \mathrm{d}^{-1}\right)\end{array}$ \\
\hline S-0 & 123,671 & 1739 & 176,764 & 2349 & 0.024 \\
S-1 & 94,852 & 1332 & 135,356 & 1799 & 0.018 \\
S-2 & 60,269 & 843 & 85,668 & 1138 & 0.011 \\
S-3 & 35,929 & 499 & 50,697 & 673 & 0.007 \\
S-4 & 118,727 & 1670 & 169,659 & 2255 & 0.023 \\
S-5 & 89,908 & 1262 & 128,251 & 1704 & 0.017 \\
S-6 & 55,325 & 773 & 78,563 & 1043 & 0.010 \\
S-7 & 30,985 & 429 & 43,592 & 579 & 0.006 \\
\hline
\end{tabular}

BOD Biochemical oxygen demand, TEQ Toxic equivalency 
Table 9 Quantity and the reduction of residual waste

\begin{tabular}{lll}
\hline $\begin{array}{l}\text { Modelled } \\
\text { scenarios }\end{array}$ & $\begin{array}{l}\text { Residual waste (t } \\
\left.d^{-1}\right)\end{array}$ & $\begin{array}{l}\text { Reduction of residual waste } \\
(\%)\end{array}$ \\
\hline S-0 & 358.8 & - \\
S-1 & 273.3 & 24 \\
S-2 & 170.7 & 54 \\
S-3 & 98.5 & 73 \\
S-4 & 341.1 & 5 \\
S-5 & 255.6 & 29 \\
S-6 & 153.0 & 57 \\
S-7 & 80.8 & 78 \\
\hline
\end{tabular}

In S-7, the maximum emission reductions of lead, mercury, cadmium, biochemical oxygen demand and dioxins were found to be approximately $75 \%$ as compared to baseline scenario.

Table 9 shows quantity of residual waste in total waste management system. In case of S-0, the maximun residual waste was found as $358.8 \mathrm{t} \mathrm{d}^{-1}$ due to larger quantity of landfilling. On the other hand, the minimum residual was found in $\mathrm{S}-7$ as $80.8 \mathrm{t} \mathrm{d}^{-1}$. In addition the maximum reduction of residual waste was found in S-7 as $78 \%$.

Table 10 repersents amount of energy consumption or recovery of modelled scenarios in various waste management techniques. The maximum net energy recovering were found in S-4 (-1491 GJ d $\left.\mathrm{d}^{-1}\right), \mathrm{S}-5$ (-1494 GJ d $\left.\mathrm{d}^{-1}\right)$, S-6 (-1499 GJ d $\left.\mathrm{d}^{-1}\right)$ and S-7 (-1502 GJ d $\left.{ }^{-1}\right)$ considering the large contribution of virgin material displacement credit $\left(-2276\right.$ GJ $\left.\mathrm{d}^{-1}\right)$. The variation of net energy recovery among these scenarios was insignificant, or the minimum net energy recovering were found in $\mathrm{S}-0$ $\left(-962\right.$ GJ d $\left.d^{-1}\right)$, S-1 (-966 GJ d $\left.{ }^{-1}\right)$, S-2 (-971 GJ d $\left.d^{-1}\right)$ and S-3 (-974 GJ d $\left.\mathrm{d}^{-1}\right)$. In case of all the scenarios, net energy recovery increases with the increase in the percentage of recycling, although amount of energy is

Table 10 Energy consumption in different modelled scenarios

\begin{tabular}{llllllll}
\hline Modelled & \multicolumn{7}{l}{ Energy consumed or recovered (GJ d $\left.{ }^{-1}\right)$} \\
\cline { 2 - 8 } scenarios & $\mathrm{R}$ & $\mathrm{C}$ & $\mathrm{L}$ & TWMS & VMDC & RRM & Net LCl \\
\hline S-0 & 0.03 & 0.26 & 76.4 & 76.7 & -1509 & 470 & -962 \\
S-1 & 0.03 & 0.26 & 76.4 & 76.7 & -1509 & 470 & -966 \\
S-2 & 0.37 & 0.26 & 67.7 & 68.3 & -1509 & 470 & -971 \\
S-3 & 0.50 & 0.26 & 64.3 & 65.1 & -1509 & 470 & -974 \\
S-4 & 0.03 & 0.40 & 75.8 & 76.2 & -2276 & 709 & -1491 \\
S-5 & 0.19 & 0.40 & 71.8 & 72.4 & -2276 & 709 & -1494 \\
S-6 & 0.37 & 0.40 & 67.0 & 67.8 & -2276 & 709 & -1499 \\
S-7 & 0.50 & 0.40 & 63.7 & 64.6 & -2276 & 709 & -1502
\end{tabular}

$R$ Recycling, C Composting, L Landfilling, TWMS Total waste management system; VMDC Virgin material displacement credit, RRM Reprocessing of recycled materials, $L C l$ Life cycle inventory insignificant compared to other waste management technique.

\section{Conclusions}

The main conclusions drawn from the present study are as follows:

(i) Scenario 7 has the least emission of greenhouse gases, acidic gases, smog precursors, heavy metal and organics to air as well as to water than that of all other scenarios.

(ii) Scenarios 4 to 7 consume less energy compared to other scenarios.

(iii) Scenario 7 has the minimum residual waste than that of all other scenarios.

Therefore, it can be concluded that scenario 7 is the best waste management system for Khulna city of Bangladesh.

\section{Acknowledgements}

The authors wish to express thanks to Khulna University of Engineering \& Technology for the financial support to complete this research. The authors of this article also wish to express thanks to all officers and staff of conservancy the department of Khulna City Corporation for providing relevant data and assistance in this study.

\section{Authors' contributions}

Both authors read and approved the final manuscript.

Competing interests

The authors declare that they have no competing interests.

\section{Publisher's Note}

Springer Nature remains neutral with regard to jurisdictional claims in published maps and institutional affiliations.

\section{Author details}

${ }^{1}$ Institute of Disaster Management, Khulna University of Engineering \& Technology, Khulna 9203, Bangladesh. ${ }^{2}$ Department of Civil Engineering, Khulna University of Engineering \& Technology, Khulna 9203, Bangladesh.

Received: 14 June 2018 Accepted: 12 March 2019

Published online: 30 April 2019

\section{References}

1. Jeswani HK, Azapagic A. Assessing the environmental sustainability of energy recovery from municipal solid waste in the UK. Waste Manag. 2016; 50:346-63.

2. Tulokhonova A, Ulanova O. Assessment of municipal solid waste management scenarios in Irkutsk (Russia) using a life cycle assessmentintegrated waste management model. Waste Manage Res. 2013;31:475-84.

3. Demirbas A. Waste management, waste resource facilities and waste conversion processes. Energ Convers Manage. 2011;52:1280-7.

4. Islam MS, Moniruzzaman SM, Alamgir M. Simulation of sustainable solid waste management system of Khulna city in Bangladesh through life cycle assessment. In: 16th International Waste Management and Landfill Symposium. Cagliari; 2017 Oct 2-6.

5. Ahsan A, Alamgir M, El-Sergany MM, Shams S, Rowshon MK. Nik Daud NN. Assessment of municipal solid waste management system in a developing country. Chin J Eng. 2014;2014:561935.

6. Alamin M, Hassan KM. Life cycle assessment of solid wastes in a university campus in Bangladesh. In: Wastesafe 2013 - 3rd International Conference on Solid Waste Management in Developing Countries. Khulna; 2013 Feb 10-12. 
7. Moniruzzaman SM, Bari QH, Fukuhara T. Recycling practices of solid waste in Khulna city, Bangladesh. J Solid Waste Tech Manag. 2011;37:1-15.

8. Bari QH, Mahbub Hassan K, Haque R. Scenario of solid waste reuse in Khulna city of Bangladesh. Waste Manag. 2012;32:2526-34.

9. European Commission. Directive 2008/98/EC of the European parliament and of the council of 19 November 2008 on waste and repealing certain directives. Official J Eur Union. 2008;312:3-30.

10. Ozeler D, Yetis U, Demirer GN. Life cycle assesment of municipal solid waste management methods: Ankara case study. Environ Int. 2006;32:405-11.

11. Ogundipe FO, Jimoh OD. Life cycle assessment of municipal solid waste management in Minna, Niger state, Nigeria. Int J Environ Res. 2015;9:1305-14.

12. Al-Salem SM, Lettieri P. Life cycle assessment (LCA) of municipal solid waste management in the state of Kuwait. Eur I Sci Res. 2009;34:395-405.

13. Seo ESM, Kulay LA. Life cycle assessment: management tool for decisionmaking. J Integr Manag Occup Health Env. 2006;1:1-24.

14. White P, Franke M, Hindle P. Integrated solid waste management: a life cycle inventory. 2nd ed. Gaithersburg: Aspen Publication; 1999.

15. Rodriguez-Iglesias J, Maranon E, Castrillon L, Riestra P, Sastre H. Life cycle analysis of municipal solid waste management possibilities in Asturias, Spain. Waste Manage Res. 2003;21:535-48.

16. McDougall FR, Hruska JP. Report: the use of life cycle inventory tools to support an integrated approach to solid waste management. Waste Manage Res. 2000;18:590-4.

17. McDougall FR. Life cycle inventory tools: supporting the development of sustainable solid waste management systems. Corp Env Strat. 2001;8:142-7.

18. Clift R, Doig A, Finnveden $G$. The application of life cycle assessment to integrated solid waste management: part 1 - methodology. Process Saf Environ. 2000;78:279-87.

19. Alamgir M, Ahsan A, Bari QH, Upreti BN, Bhatttari TN, Glawe U, et al. Present scenario of municipal solid waste and its management. In: Alamgir $\mathrm{M}$, McDonald C, Roehl KE, Ahsan M, editors. Integrated management and safe disposal of solid waste in least developed Asian countries - a feasibility study. Khulna: Wastesafe Publication; 2005. p. 135-228.

Ready to submit your research? Choose BMC and benefit from:

- fast, convenient online submission

- thorough peer review by experienced researchers in your field

- rapid publication on acceptance

- support for research data, including large and complex data types

- gold Open Access which fosters wider collaboration and increased citations

- maximum visibility for your research: over $100 \mathrm{M}$ website views per year

At $\mathrm{BMC}$, research is always in progress.

Learn more biomedcentral.com/submissions 